\title{
EXPLORING PROCESSES AND DYNAMICS OF MYSTICAL CONTEMPLATIVE MEDITATION: SOME CHRISTIAN-BUDDHIST PARALLELS IN RELATION TO TRANSPERSONAL THEORY
}

\author{
MICHAEL STOEBER \\ Regis College, University of Toronto
}

\begin{abstract}
This paper explores Christian contemplative meditation, focusing on the prayer of Recollection as it is developed especially by Evelyn Underhill (1875-1941) and St. Teresa of Avila (1550-1582). It outlines the practice and explores possible theoretical and therapeutic dynamics, including some comparative reflections of this form of Christian meditation with Buddhist Samatha Vipassanā (calming insight) meditation and Mindfulness Based Cognitive Therapy. It also draws on the transpersonal theory of philosopher Michael Washburn, in exploring resistances, obstacles, and goals of such mystical practices.
\end{abstract}

\section{NATURE AND PROCESSES OF THE CHRISTIAN PRAYER OF RECOLLECTION}

Evelyn Underhill first develops her understanding of the Christian prayer of Recollection (recogimiento) in her modern classic, Mysticism: The Preeminent Study in the Nature and Development of Spiritual Consciousness (1911). ${ }^{1}$ Underhill seems most dependent in her exposition on St. Teresa of Avila's sense of the practice, though she does mention other Christian mystics in this context. ${ }^{2}$ In Mysticism, she locates Recollection as the

\footnotetext{
${ }^{1}$ Evelyn Underhill, Mysticism: The Preeminent Study in the Nature and Development of Spiritual Consciousness (New York: Image Book, Doubleday, 1990 [1911]), hereafter cited in brackets in the text-body as $(M)$ including the page number.

${ }^{2}$ Underhill makes reference to a number of Christian mystics in her development of the prayer of Recollection, including Jacob Boehme, Richard of St. Victor, Meister Eckhart, Jan van Ruusbroek, Madame Guyon, and, in particular, St. Teresa of Avila. For
} 
first degree of contemplative prayer - as preceding higher levels of what she calls meditative 'Quiet' and 'Contemplation'. It is distinguished from these more advanced states by the increased degree of passivity and openness to Spirit that occurs as one makes progress in the practice. She later provides a more practical exposition of Recollection in Practical Mysticism (1914), ${ }^{3}$ where she defines it formally as 'the disciplining and simplifying of the attention' or 'the subjection of the attention to the control of the will' ( $P M 65,69)$. As such, it is not a strictly religious phenomenon, but a psychological ability one can acquire which narrows or concentrates one's field of consciousness. Generally speaking, she writes, Recollection 'is a form of spiritual gymnastics' ( $M$ 316). More specifically, in religious mysticism, Recollection is the concentration on a specific image or object with the intention of becoming aware of one's core spiritual nature and its relation to God. She claims that one finds the

Teresa's discussion of this contemplative practice, see especially Teresa's Way of Perfection, Vol. II, The Complete Works of St Teresa of Jesus, trans. by Allison Peers (London: Sheed and Ward, 1946) Chapters 28-31, and Interior Castle, trans. by E. Allison Peers (N.Y.: Image Books, Doubleday, 1961), First and Second Mansions.

In turn, Teresa herself is heavily dependent on a Franciscan writer about twenty years her senior, Francisco de Osuna (1492/97-1541?), who describes Recollection in some detail in The Third Spiritual Alphabet, including the prayers of Quiet and Contemplation/ Union under its general heading. Osuna teaches in this treatise: i) that mystical communion with God is available in this life; ii) that this requires an apophatic approach where memory, will, and understanding cease their normal modes of operation; iii) that Recollection is a form of devotion that withdraws a person into an inner solitude that becomes open to underlying spirit; iv) and that it culminates in an infused prayer where the perfectly advanced mystics rise above themselves and live and act out of this illumined condition. For a helpful overview, see Mary E. Giles, 'Introduction', in Francisco de Osuna: The Third Spiritual Alphabet, trans. by Mary E. Giles (New York: Paulist Press, 1981), pp. 1-37.

In her biography, Teresa mentions her reception of this book from her uncle and its significance in introducing her to contemplative practices at about the age of twenty. The prayer of Recollection appears to be a core foundation of her spirituality. Obviously Teresa did not follow de Osuna's text in any systematic fashion and creatively adapted it to suit her own specific needs and experiences and those of her sisters. In the 1931 translation of The Third Spiritual Alphabet, the translator (a Benedictine of Stanbrook) comments in her notes on the influence of this text on specific aspects of St. Teresa's writings (London: Burns, Oates \& Washbourne, Ltd, 1931). Other Roman Catholic writers call this form of contemplative meditation the prayer of 'simple gaze' or 'simplicity', or 'the simple vision of faith'. Jordan Aumann, 'Recollection', New Catholic Encyclopedia, 2nd ed. Vol. 11 (Detroit: Gale, 2003), p. 955.

${ }^{3}$ Evelyn Underhill, Practical Mysticism (London: E.P. Dutton \& Co. Inc., 1914), hereafter cited in brackets in the text-body as $(P M)$ including the page number. 
practice in many mystical religions, though she focuses on the Christian form in her exposition.

Initially, Recollection is a deliberate and active form of meditation that attempts to re-collect all 'the scattered interests of the self' - to expel the typical discordant chatter of everyday consciousness - in centring one's attention upon a specific object. It is a voluntary 'collecting or gathering in of the attention of the self to its "most hidden cell"" $(M$ 313, 314). She says it 'is a half-way house between thinking and contemplating' ( $P M$ 71 ), where Contemplation is understood as more direct awareness and experience of God, non-mediated by normal categories of experience. Recollection is the first step of the contemplative life and the key Christian meditative practice in stimulating Contemplation. It is an exercise that enables one to shift one's conscious orientation away from the sensory world and intentional awareness, to an uninhibited openness to inner spiritual realities distinct from the senses and egoic mind.

Practically, Recollection begins with focused attention on a specific image or phrase or word. Underhill writes, '... Hindu mystics will brood upon a sacred word, whilst Christian contemplatives set before their minds one of the names or attributes of God, a fragment of Scripture, an incident of the life of Christ; and allow - indeed encourage - this consideration, and the ideas and feelings which flow from it, to occupy the whole mental field' (M 314). Later in Practical Mysticism, Underhill claims that almost any subject will do - and she cites as possibilities various aspects of nature - 'a flower, a river, the various tapestries of the sky' - and processes of human life - 'birth, growth, and death' - and of human experience - 'ideas of love, joy, peace, mercy, conflict, desire' though she claims more formal objects of traditional religion offer 'the richest and most evocative of fields' ( $P M 73$ ).

The process involves 'the primary simplification of consciousness', where the subject wilfully focuses her concentration on this selected idea or image, thereby intentionally shifting attention from the normal movement and dynamics of consciousness to the specific object of meditation (M 314). Underhill writes: 'the self ... protected by this holy day-dream from the more distracting dream of life, sinks into itself, and becomes in the language of asceticism "recollected" or gathered together'. St. Teresa uses an image of previously scattered honeybees returning to the hive. So the 'senses gather themselves together' in the practice of Recollection, and Teresa speaks of 'a simple retreat of [the sensory and cognitive] powers into the ground of the soul' (M 316). The content of 
the object of meditation is not the essential element of the process, and in some ways is irrelevant to the dynamic. Rather, the key is to acquire the discipline of prolonged concentration. Underhill describes the initial process for the typical novice:

the choice made, it must be held and defended during the time of meditation against all invasions from without, however insidious their encroachments, however 'spiritual' their disguise. It must be brooded upon, gazed at, seized again and again, as distractions seem to snatch it from grasp. A restless boredom, a dreary conviction of your own incapacity, will presently attack you. This, too, must be resisted at swordpoint. This first quarter of an hour thus spent in attempted meditation will be, indeed, a time of warfare; which should at least convince you how unruly, how ill-educated is your attention, how miserably ineffective your will, how far away you are from the captaincy of your own soul. (PM 74)

Described in this way, one can see how an attractive religious image might make a very difficult process a little easier. Recollection is a practical method intended to enable a person gradually to move through a process of introversion into her underlying spiritual centre or core - first (i) to protect or shield herself from the normal barrage of sensory phenomena, then (ii) to still the ordinary processes of conscious imagination and cognition, and eventually (iii) to gather one's attention into a specific and precise direction towards the object of meditation, where it occupies one's attention solely and completely. As meditative proficiency increases, the subject begins to identify affectionately with the object, and it takes on a special energy and affect. Underhill writes, it 'begins to take on a new significance; to glow with life and light'. '[T] he subject of your meditation begins, as you surrender to its influence, to exhibit unsuspected meaning, beauty, power. ... You sink as it were into the deeps of it, rest in it, "unite" with it; and learn, in this still, intent communion, something of its depth and breadth and height ...' (M 315, PM 75).

Underhill associates this level of mystical communion with great artists, for whom the veil between life and spiritual consciousness has become transparent, wherein they are able to perceive 'things in their native purity.' It would appear here that the specific content of the object

${ }^{4}$ Evelyn Underhill, 'The Mystic as Creative Artist', The Essentials of Mysticism (London: J.M. Dent \& Sons Ltd., 1920), pp. 65-66. Underhill speaks of the 'innocence' 
might have a very significant bearing on the psycho-spiritual dynamic, though Underhill does not explore this aspect of the contemplative process in this context, tending to situate it in the later stage of Contemplation, as we will see below. Presumably, at the level of visionary imagination the contemplative might be moved to experience in mystic union or absorption the spiritual reality underlying or supporting the image, if such exists, for example, as an angelic presence, saint, guru, or other special or divine personage. Clearly, the dangers of demonic mysticism highlight the way in which an object of meditation might affect the contemplative subject negatively, as well as positively. In terms of natural phenomena, Underhill also insists there is a common 'essence' of things that might be realized in this communion, which issues forth in quite a significant affective content. But in her account here of the Christian prayer of Recollection, she is accentuating the importance that the mystic not become preoccupied by the union with the meditative object, but to use the absorptive encounter as an instrument in shifting to the meditative condition of Quiet.

There is a gradual self-awareness that occurs in the movement, and one eventually becomes able to free oneself from typical intentional consciousness - where things are perceived solely 'in relation to our own needs, moods, and preferences'. Recollection also involves purgative elements, in helping one to recognize the way in which '[a]mbitions and affections, tastes and prejudices, are fighting for [one's] attention' - the way in which one's relations to things have been coloured by egoistic desires $(P M 56,59)$. A person becomes able to detach from conscious emotional connections with objects of the phenomenal world. Underhill notes the self-empowerment that surfaces in Recollection: 'You, in this

and receptive 'humility' of the artist, who is able to 'live a life in which the emphasis lies on sensation rather than on thought: for the state which [the artist] then struggled to describe was that ideal state of pure receptivity, of perfect correspondence with the essence of things, of which all artists have a share, and which a few great mystics appear to have possessed - not indeed in its entirety, but to an extent which made them, as they say, "one with the Reality of things". The greater the artist is, the wider and deeper is the range of this pure sensation' ( $P M$ 42-43). Great artists both delight and enlighten people through their ability to represent in their work something of the nature of their mystical experiences, which at times can even stimulate in sensitive art aficionados their own mystical experiences. She refers to William Blake: great artists '[c]leanse the doors of perception, so that everything might appear as it is - infinite'. 'The Mystic as Creative Artist', p. 65. 
preliminary movement of recollection, are saying your first deliberate No to the claim which the world of appearance makes to a total possession of your consciousness ... ' 5 So a person becomes able to observe things free of previous attachments and dependencies - free from what she calls 'the cooking, filtering process of the brain' - and to act from a newly found position of purity, simplicity, and humility $(P M 45,76){ }^{6}$

\section{NATURE AND PROCESSES OF BUDDHIST INSIGHT MEDITATION}

The parallels between this view of Recollection and Buddhist Samatha Vipassanā (calming insight) meditation seem significant. Briefly, 'mindfulness' or 'skilful attentiveness' (sati) is a key tool of Buddhist Insight meditation, which developed in traditional forms of Therāvada Buddhism. The goal of this practice is to cultivate a constant and sustained investigation or self-reflection of what is going on within oneself, in order ultimately to awaken to Reality as it really is in the Nibbāna experience. There are varied possible foci of Insight meditation, but a significant traditional text, the Satipațthāna Sutta (The Foundation of Mindfulness), distinguishes four foundations or major categories of meditative attention: i) actions and conditions of the body, including the breath; ii) feelings of the body; iii) mental states; iv) and Buddhist dhamma (teachings)..$^{7}$ A clear and concise contemporary account given

${ }^{5}$ In highlighting this issue, Valentin Tomberg distinguishes between interested and disinterested concentration. He writes: 'A monk absorbed in prayer and an enraged bull are, the one and the other, concentrated. But the one is in the peace of contemplation whilst the other is carried away by rage. Strong passions therefore realize themselves as a high degree of concentration.' Recollection is a meditative process intended to free the will of 'enslaving passions, obsessions, and attachments ...', as Tomberg would describe it, rather than a concentration that is driven by obsession. As such, as we will see, it can have a therapeutic effect on practitioners. Robert A. Powell, tr., Meditations on the Tarot: A Journey into Christian Hermeticism (Rockport, MA: Element, Inc., 1991), p. 9. My thanks to Glenn McCullough for pointing out this reference to Tomberg.

${ }^{6}$ Underhill writes also: 'Now turn this new and purified and universal gaze upon yourself. Observe your own being in a fresh relation with things, and surrender yourself willingly to the moods of astonishment, humility, joy - perhaps of deep shame or sudden love - which invade your heart as you look.' (PM 76)

${ }^{7}$ Under these categories, the body (i) includes the breath, four postures, basic bodily acts, bodily impurities, and death; sensations (ii) include pleasant, unpleasant and the indifferent; the mind (iii) includes various moods and states; and Buddhist teachings (iv) include the five hindrances or vices (lust, anger, sloth, restlessness, and doubt), the five skandhas (categories of existence: matter, sensations, perceptions, moods, thoughts), 
in a Theravādan Thai lineage tradition includes: 'Body-sweeping' a process that attempts to collect one's attention in exploring what is currently going on in terms of one's bodily sensations, feelings, and thoughts; anāpannasati is breath meditation, where the focus is on one's breath rather than one's body - constantly and gently bringing one's wandering attention back to the breath; the cultivation of good will or mettā, where one visualizes one's breath as light and kindness or tolerance or forgiveness, and directs this first to oneself then beyond oneself to others; and 'bare attention' or 'choiceless awareness', where the subject proceeds without a meditating object, continuously pushing aside objects that arise in one's consciousness. ${ }^{8}$

Such practices lead to positive changes in consciousness. Insight meditation is a process of constantly letting go of the inner chatter that interferes with the 'mind-full' attention of a chosen object of attention. The practice enables one eventually to recognize negative feelings, thoughts, and attitudes, and to cease to be attached to them. A contemporary Theravādan monk summarizes the therapeutic possibilities:

... with the practice of insight meditation you discover a space in which to stand back a little from what you think you are, from what you think you have. Contemplating these perceptions, it becomes clear that you don't have any thing as 'me' or 'mine'; there are simply experiences, which come and go through the mind. So if, for example, you're looking into an irritating habit, rather than becoming depressed by it, you don't reinforce it and the habit passes away. It may come back again, but this time it's weaker, and you know what to do. Through cultivating peaceful attention, mental content calms down and may even fade out, leaving the mind clear and refreshed. Such is the ongoing path of insight. ${ }^{9}$

In both Christian Recollection and Buddhist Insight meditation, then, participants become familiar with their thoughts and feelings and their

six senses (sight, sound, smell, taste, touch, thought), the seven positive conditions or practices (mindfulness, analysis, passion, enthusiasm, tranquillity, concentration, and equanimity). Rupert Gethin writes: 'Upatissa's Vimuttimagga ('Path of Freedom') and Buddhaghosa's Visuddhimagga give standardized lists of thirty-eight and forty objects of meditation (kammațhāna) respectively', the specific suitability of which depends upon the needs and nature of one's personality. Rupert Gethin, The Foundations of Buddhism (New York: Oxford University Press, 1998), p. 177.

8 Abhayagiri Buddhist Monastery, Introduction to Insight Meditation (Redwood Valley, CA: Sanghapala Foundation), pp. 4-14.

${ }^{9}$ Abhayagiri Buddhist Monastery, Introduction to Insight Meditation, pp. 17-18. 
processes and patterns, and are able to free themselves from habitual attachments to them. In line with current thinking in Mindfulness Based Cognitive Therapy (MBCT) ${ }^{10}$ these kinds of contemplative meditation gradually enable practitioners to separate bodily and psychic phenomena from their self-identities, which can lead to an inner and outer freedom with respect to obsessive memories and distorted thought patterns, and to healing from certain mood disorders. Mindfulness meditation is thought to enable clients to focus on direct and current sensory experiences (to improve 'ability to rest in the present moment') and to maintain such focus, apart from negative memories and feelings, to which they have been obsessively attached. It allows practitioners to recognize, detach and reframe themselves away from distorted emotions, habits, and behaviours that are painful or destructive. In MBCT, this Buddhist practice is regarded as a non-pharmacological therapeutic response to stress, anxiety, depressive mood states, obsessive thinking, substance abuse, chronic pain, and even suicidal behaviour. ${ }^{11}$

\section{RECOLLECTION, QUIET, AND CONTEMPLATION}

Underhill speaks of the positive, purgative effects of the prayer of Recollection in terms of a new and purified self-understanding that allows for a deep level of serenity and simplicity, while Buddhist teachers and MBCT therapists suggest significant personality enhancements through the practice of Mindfulness meditation. Nevertheless, however positively therapeutic these meditative practices might be, traditional Christian and Buddhist accounts of the contemplative dynamics suggest this is just the beginning of the mystical path. The practice of Christian meditative Recollection eventually shifts into what Underhill calls the prayer of Quiet, as the subject eventually stops the willed concentration on the object of Recollection and simply rests passively within this deep inner consciousness, free of all sensory and cognitive attachments.

${ }_{10}$ Current popular figures in Mindfulness Based Cognitive Therapy are Joseph Goldstein, Nancy Hamilton, Jon Kabat-Zinn, Jack Kornfield, Sharon Salzburg, Zindel Segal, and Mark Williams.

${ }^{11}$ J. Mark Williams, D.S. Duggan, C. Crane, M, J. V. Fennell, 'Mindfulness-Based Cognitive Therapy for Prevention of Recurrence of Suicidal Behavior', Journal of Clinical Psychology: In Session, vol. 62/2 (2006), 201-210; quotation from p. 207. See also a special issue on 'Mindfulness: Diverse Perspectives on its Meaning, Origins, and Multiple Applications at the Intersection of Science and Dharma', introduction by Mark G. Williams and Jon Kabat-Zinn, Contemporary Buddhism, vol. 12/1 (May 2011). 
Although Underhill speaks theologically of this condition as an awareness of the soul's unity with its ground or 'Pure Being', she describes it as 'an almost complete suspension of the reflective powers' that leads to a radically passive condition that mystics have called in negatively descriptive language 'ecstatic deprivation', 'nothingness', 'utter stillness', 'Interior Silence', or 'emptiness'. This altered state of consciousness is a kind of consciousness-purity that is not properly describable and is best characterized by silence. Although quite positively affective, mystics speak of the 'naked orison' or 'divine dark' of this state of consciousness purity, in contrast to the normal busy activities of the sensory-cognitive intentional mind ( $M$ 317, 318, 324, 308).

There seem to be parallels with Buddhist accounts of the more quietistic experiences of formless absorption (arüpa jhāna) that occur in the samādhi (concentration) condition, though these provide more speculative detail than that given in Christian contexts. Henepola Gunaratana describes these as 'states of deep mental unification which result from the centring of the mind upon a single object with such power of attention that a total immersion in the object takes place. ${ }^{12}$ These are thought to be radically apophatic, altered-state experiences of (i) infinite space, (ii) of the infinite consciousness that is able to appreciate such boundless space, (iii) of nothingness or the void at the base of such an awareness, or (iv) of both neither-perception-nor non-perception, which attempts to name the radical 'subtle' perception at work in this formless absorption. These conditions are greater and greater refinements of the quality of one-pointedness attention and equanimous feeling that follow upon preceding jhānas of form or matter, and they are regarded as subjective correlates to objective spheres or planes of reality. Hence, none of these conditions of absorption are sufficient for Nibbāna, which requires a further qualitative shift into a higher consciousness of Reality as it truly exists, which transcends completely the mind and senses and our natural perceptual distortions. ${ }^{13}$ The experiences of levels of formless

${ }^{12}$ Henepola Gunaratana, The Jhanas in Theravada Buddhist Meditation (Kandy, Sri Lanka: Buddhist Publication Society, 2009), Chapter 1, 'The Doctrinal Context of Jhana' on the Access to Insight: Readings in Theravada Buddhism website (2007), available at $<$ http://www.accesstoinsight.org/lib/authors/gunaratana/wheel351.html> [accessed 2 February 2014].

13 Gunaratana, The Jhanas in Theravada Buddhist Meditation, Chapter 4, 'The Immaterial Jhanas'. Henepola Gunaratana states in this chapter: the mind 'has attained the most intense degree of concentration, becoming so refined that consciousness can 
absorption only support the movement to Nibbāna, and will actually hinder it, if they are regarded as ideal or final states of being.

Similarly, in the Christian tradition, when forms of passive consciousness have been regarded as ideal states, this condition of Quiet has been criticized as misguided, dangerous, and heretical. ${ }^{14}$ In orthodox Christian mystical contexts the novice is encouraged not to rest in this quietist absorption, however attractive and comfortable this experience might be, but to become open to a transitional shift, where meditative Quiet ideally opens to an awareness of various dynamic spiritual realities, in a movement from 'passive' to 'infused' Contemplation. So Underhill speaks of coming eventually to recognize through this process of selfgathering one's underlying spiritual Self or Soul: 'you will at last discover that there is something within you - something behind the fractious, conflicting life of desire - which you can recollect, gather up, make effective for new life. You will, in fact, know your own soul for the first time ...' (PM 76-77) More significantly, through the regular practice of Recollection, the object of meditation gradually transforms into a kind of opening or medium into the spiritual realm. She writes, 'It ceases to be a picture, and becomes a window through which the mystic peers out into the spiritual universe and apprehends to some extent - though how, he knows not - the veritable presence of God' (M 315).

In traditional Christian mysticism, the meditative Quiet naturally shifts into the prayer of Contemplation or Union, as St. Teresa calls it, which involves a much more receptive stance than the active orientation

no longer be described in terms of existence or non-existence. Yet even this attainment, from the Buddhist point of view, is still a mundane state which must finally give way to insight that alone leads to true liberation'.

${ }^{14}$ Underhill clarifies the key characteristics of mystical Quietism: 'Pure passivity and indifference were its ideal. All activity was forbidden it, all choice was a negation of its surrender, all striving was unnecessary and wrong. It needed only to rest for evermore and "let God work and speak in the silence". (M 325) St Teresa mentions how the mystic in Quiet fears to lose the absorption by any movement of the faculties or the body: 'they seem not to be in the world, and have no wish to see or hear anything but their God' (Way of Perfection, xxi, p. 128). The problem arises when the mystic hopes to remain permanently within this isolated altered state of consciousness, and thereby resists opening to other features of spiritual Reality. Teresa suggests that this is especially common with persons whose physical limitations lead the body to become overwhelmed by the absorption of the soul, so they fall into a kind of stupor - which they mistake for rapture, where in fact rapture is a higher level experience that involves more dynamic elements. Interior Castle, 4.3, p. 93. 
of Recollection. She speaks of 'infused' rather than the earlier 'natural' Contemplation, highlighting at this stage the action of the Divine upon the receptive person, which includes various kinds of mystical rapture, vision, and unity at the level of Contemplation: ecstatic mystic transports, intellectual visions of the Divine Presence, imaginary visions and numinous light, panentheistic unity, and experiences of mystical affliction. ${ }^{15}$ Recollection is a meditative prayer that stimulates movement to meditative Quiet and then to a radical passive opening to a wide variety of mystical experiences associated with Christian Contemplation. Underhill writes:

The degrees of Recollection trained the self in spiritual attention: and at the same time lifted it to a new level of perception where, by means of the symbol which formed the gathering of its powers, it received a new inflow of life. In the degrees of Quiet it passed on to a state characterized by a tense stillness, in which it rested in that Reality at which, as yet, it dared not look. Now, in Contemplation, it is to transcend alike the stages of symbol and silence; and 'energize enthusiastically' on those high levels which are dark to the intellect but radiant to the heart. (M 328-329)

\section{RESISTANCE AND OBSTACLES TO RECOLLECTION, QUIET, AND CONTEMPLATION}

I mentioned above the initial resistances and difficulties of meditation. Anyone who has tried some modern form of Christian Contemplation ${ }^{16}$ can attest to the discomfort and disquiet that initially ensues with its practice. One cannot help but be distracted by the clutter and chatter of one's sensory field and inner world of thoughts, feelings, attractions, and memories, which in some contexts can become quite negative, depressing, and debilitating to the meditative practice. St. Teresa and Underhill understand the prayer of Recollection within an arduous process of moral-spiritual purification involving the overcoming of various distracting habits and distortions that inhibit one's openness to

15 Teresa, Interior Castle, 'Sixth Mansions', pp. 126-203.

${ }^{16}$ Popular versions include the Centering Prayer of Basil Pennington and Thomas Keating and John Main's Christian Meditation. In their development, these contemporary movements appear to be influenced more by teachings found in the Cloud of Unknowing, the Conferences of John Cassian, and elements from Buddhist and Hindu traditions, than by St Teresa's version of Recollection. Thanks to Jaegil Lee, for bringing these influences to my attention. 
spiritual Reality. According to Underhill, Recollection typically stirs up one's awareness of personal limitations and deficiencies - of distorted attractions - such as sensual fantasies and desires, obsessions, and addictions - of negative feelings and emotions - such as envy, malice, fear, and anger - and of debilitating attitudes - such as selfishness, pride, indolence, and lust. These various mental-emotional phenomena dominate and clutter up one's psychic space and inhibit one's ability to concentrate meditatively. Recollection enables one to become conscious of these distorted feelings, patterns, and attitudes - it enables an awareness that acts to dis-empower them, paralleling or even reflecting the therapeutic dynamics we find in Mindfulness meditation. However, beyond this level of initial resistance, there appear to be other serious obstacles to the transformative movement, as Teresa's menacing imagery suggests. She speaks of 'snakes and vipers and poisonous creatures', of 'wild beasts and animals', and of 'devils' which are on the prowl, actively hindering the transformative dynamic, harassing and assaulting the contemplative. ${ }^{17}$

Michael Washburn's theory of transpersonal psychology ${ }^{18}$ expands creatively on these resistances, in proposing how meditation contributes to a process of psychological and spiritual transformation. Washburn sees traditional forms of Patanjali's Hindu yoga as the primary example of what he calls 'Concentrative Meditation' (CM) - which 'maintains a singularity of focus', while Buddhist Vipassanā is the main example of 'Receptive Meditation' (RM) - which involves 'sustained nonselective alertness. ${ }^{19}$ Regarding his latter claim, certainly at the level of the arūpa

17 Teresa, Interior Castle, pp. 40-41, 47-48, 52, 56.

${ }^{18}$ Transpersonal psychology is sometimes called 'spiritual psychology', which highlights the significance granted to spirituality in this branch of psychology. It tends to focus on mystical or other peak experiences in presuming that the ego can be transcended in psychic movements into higher states of consciousness. It is interdisciplinary in method, drawing on many humanistic disciplines in its development, especially humanistic and developmental psychology, psychosynthesis, and analytic psychology. Major figures in transpersonal psychology are Jorge Ferrer, Stanislav Grof, Michael Washburn, and Ken Wilbur.

19 Washburn gives as examples of RM Vipassanā, Zazen, devotional prayer, and Recollection, and as examples of CM he lists Patanjali's Yoga, Koan exercises, visualizing meditations, and Recollection. I would add contemporary Centering Prayer and Christian Meditation to the list of CM and Hesychast or the Jesus Prayer to both RM and CM. The Ego and the Dynamic Ground: A Transpersonal Theory of Human Development, 2nd rev. ed. (Albany: SUNY Press, 1995), pp. 153-157. Hereafter this text is cited in brackets in 
jhänas (formless absorption) this is the case, but as we have described the practice of Mindfulness meditation in Samatha Vipassana, it involves initial focus on various possible objects of concentration (CM), so would seem to include both CM and RM. Rather similarly, Washburn observes that the Christian prayer of Recollection involves both Concentrative and Receptive forms of meditation. It begins discursively, selectively concentrating on a specific idea, image, or object $(\mathrm{CM})$, then in the prayer of Quiet shifts from the stilled equanimity that this movement has induced into a 'posture of nondiscursive receptivity', were the person simply 'waits, vigilantly and without interruption, to be touched by spiritual power' (RM) (E2 157).

We could also add to this list the Hesychast prayer in Eastern Christian Orthodox traditions, where concentrated repetition of the phrase 'Lord Jesus Christ, Son of God, have mercy on me, the sinner', sometimes combined with certain bodily postures and breath movements, culminates ultimately in a condition of radically passive stillness and openness (kenosis) to spiritual Energies. The important point here, however, is that both CM, which leads the subject into a condition of absorption, and RM, which leads the subject into a witnessing of consciousness, involve 'the practice of unmoving and unmediated attention', by 'which the ego releases consciousness from its grasp'. Washburn argues that both kinds of meditation not only help to bring to conscious awareness regular patterns of thought and feeling, as claimed by Underhill and in MBCT, but they also stimulate an opening to aspects of one's personal unconscious and the collective unconscious (E2 153, 155, 160). ${ }^{20}$

This 'transpersonal' process for the mystic is complex and somewhat idiosyncratic and not necessarily as smoothly sequential as the formal ordering that is given in theoretical accounts suggests, but can be outlined in relatively simple terms as it applies across different religions. Through meditative practices, a person becomes aware of habitual patterns of

the text-body as (E2) including page numbers. I will cite reference in the text-body to the first edition of this text (1988) as (E1) including page numbers.

${ }^{20}$ Washburn writes: 'Many Western churches have gone out of their way to stress the differences between Eastern meditation and Western prayer, sometimes going so far as to claim that forms of Eastern meditation are not forms of spiritual practice at all. This stress on difference has not been helpful at all. According to the foregoing account, meditation and prayer are sibling species of a single genus. They are both practices of unmoving and unmediated attention, and they both unfold through the same basic sequences of stages. Moreover, ... they both have similar effects upon the psyche, accessing the unconscious in much the same way.' (E2 157) 
feeling and thinking, and eventually is able to still or stop them, and to free herself from its underlying infrastructure or embedded structures. The normal activities of the ego - internal dialogue and fantasy, cognitive activity, and intentional orientations - are first brought to light and halted through meditative actions of letting go, not doing, or undoing. This corresponds to the positively therapeutic function that Mindfulness and Recollection meditation might serve in helping a person to recognize and detach herself from distorted patterns of thinking and feeling. However, according to Transpersonal theory, continued meditation carries the process more deeply, to uncover, penetrate and eventually dissolve the ego's infrastructure. The underlying mediating structures of consciousness - 'ingrained sets and stances, pre-established cognitive programs and filters, ego armours and defence mechanisms' - undergo a process of uncovering, exposure, and disengagement (E2 160).

Transpersonal psychologists call this the 'personal embedded unconscious'. It includes tendencies and patterns, postures, masks, affections, core life-determining experiences, ingrained patterns of responses caused by trauma (complexes), and other nuclear elements of ego identity that are often rooted in early childhood, in the relationships with the parents and other early social experiences. Insofar as this process helps a person to overcome psychological imbalances or distortions, it can be quite positive in reducing depression and anxieties associated with certain mental/emotional disorders. However, as this uncovering and disengaging of the personal embedded unconscious continues, this will also lead to the de-repression of what transpersonal psychologists call the 'personal submerged unconscious' that underlies these filters. This includes that which the ego dissociates from its identity or selfconcept (the Jungian shadow) - 'the dark and disowned dimensions of the personality', such as childish impulses and contra-sexual elements (E2 149) - as well as the most deeply repressed traumatic experiences of the person that underlie that phenomenon. Recollection leads a person eventually to expose her or his unconscious distortions, deficiencies, ingrained patterns, defence mechanisms, dark impulses, and underlying emotional wounds.

If such a psychological account of the dynamic is accurate, we can begin to appreciate why Teresa uses such ominous imagery to describe the difficulties and to understand why mystics traditionally speak of the incredible arduousness of the purgative aspects of the movement. 
Underhill notes that the positive experiences of Contemplation are 'always paid for by psycho-physical disturbances' ( $M$ 363). Throughout this process of mystical ascesis, the ego is losing its identity, autonomy, and control of the personality, thus contributing to chronic fear, anxiety, and dread - quite the opposite of the initially positive therapeutic effects of Recollection and Mindfulness meditation. The picture is further compounded in Washburn's transpersonal account by its postulation of the immersion of the egoic-self into the pre-personal or collective unconscious beyond the personal unconscious. Drawing from Freudian theory, Washburn postulates a 'primal repression' whereby the prepersonal instinctual impulses of the infant are repressed before the Oedipal period of the child's development. Stimulated by meditative practices much later in life, these deeply repressed instincts of the adult mystic gradually resurface to consciousness, and require personal reintegration with the transforming egoic-self.

Drawing also on Jungian theory, Washburn speaks of the instinctualarchetypal unconscious'. This psychic-spiritual realm involves elements crucial both to our emergence as individual organisms (ontogenetic) and our constitution and survival as a species (phylogenetic) (E2 120$121,199)$. Archetypes are primal energies of the psyche that are key to personal individuation and reveal themselves in dreams and other altered-state visions as symbols of personal characters, or events or transformation. ${ }^{21}$ Mystical de-repression disables the filtering system that normally inhibits the influx of these energies and realities, and leaves the person much more vulnerable to their impact and influence. So mystics experience voices and visions of various types, intensities, and magnitudes, and their imagination and fantasy life are very creatively stimulated and pronounced. ${ }^{22}$ This vital energy is also manifested in marked bodily experiences that include 'spasms, snapping sensations,

21 Examples of Jungian Archetypes include the Self, Shadow, Anima/Animus, and Persona. They can appear in dreams or meditative states as symbols of personal characters - such as the great mother, the old wise man, child, hero martyr, or the devil - or as symbols of events or transformations, such as death, birth, cataclysms, or apocalypse.

${ }^{22}$ For extensive illustrative examples, see chapters III, V and VIII, 'Purification of the Self', 'Voices and Visions' and 'Ecstasy and Rapture', in Underhill, Mysticism, Part II, pp. 198-231, 266-295, 358-379, and various sections of St Teresa's Way of Perfection, The Life of Saint Teresa of Avila By Herself, J. M. Cohen (trans.) (N.Y.: Penguin Books, 1957), and especially Interior Castle, 6.i-xi, pp. 126-203. 
and a variety of spontaneous movements and vocalizations', and there are paranormal phenomena associated with mysticism that perhaps can be explained in reference to this direct opening of consciousness to this primal energy source (E2 215). ${ }^{23}$ Mystical de-repression can bring tremendous charismatic power, heightened creative energy, feeling, and imagination, and enhanced sexuality. So, for example, negatively, St. Catherine of Sienna was accosted in her cell by visions of lascivious creatures seeking sexual favours, who even chased her into the Church to which she fled for protection; and, very positively, St. Teresa experienced the transverberation, the repeated piercing of her heart and entrails with a spear by an angel, that left her 'all on fire with a great love of God' ( $M$ $392,292) .^{24}$

Washburn relates such erotic mystical phenomena at least in part to primal instincts connected with our constitution and development as a species (phylogenetic). These instinctual constituents pertain to sex, child-care, self-defence, and food-acquisition. They also have to do with universal human situations, such as birth, major life-transitions, and death (E1 124). Survival and situational instincts that are normally under the control of the ego, such as sexuality, aggression, and fear, can come to invade and even overwhelm one's personality, as Recollection uncovers or awakens aspects of the pre-personal unconscious. Meditative practices eventually break down the normal checks and balances of very powerful primitive impulses. As unconscious force and content surface in the transformative process, they can contribute to various degrees of ego inflation, perhaps even to diabolical mysticism, rather than an overcoming of narcissistic tendencies and a movement to spiritual integration. So Teresa remarks about the grave obstacles and dangers of the spiritual path: 'our faculties seem to be making war upon us, as if they were resentful of the war made upon them by our vices'. 'It is really a perfect misery to be alive when we have always to be going about like men with enemies at their gate, who cannot lay aside their arms even when eating or sleeping, and are always afraid of being surprised by

${ }^{23}$ See for example Herbert Thurston, The Physical Phenomena of Mysticism (Chicago: H. Regnery Co., 1952) and Surprising Mystics (London: Burns and Oates, 1955), where he explores historical cases in Christian mysticism of purported levitation, stigmata, telekinesis, bodily elongation, resistance to flames and heat, luminous phenomena, incorruption, blood prodigies, and other abnormal phenomena, many of which are supported by apparently reliable witnesses and documentation.

${ }^{24}$ St. Teresa, The Life of Saint Teresa of Avila By Herself, pp. 210-211. 
a breaching of the fortress in some weak spot. Oh, my Lord and my God! How canst Thou wish to desire such a miserable life as that?'25

Washburn observes parallel accounts concerning this collective unconscious material given by some Buddhists, citing Buddhaghosa's commentary on ten categories of imperfections: illumination, knowledge, rapture, happiness, tranquillity, bliss, resolution, exertion, assurance, equanimity, and attachment. These are powerful mystical experiences that arise as one progresses in meditative practice, which can hinder a person from the movement to Nibbāna, insofar as she or he regards them as ultimate or they accentuate a false sense of substantial self. ${ }^{26}$ Washburn also mentions makyo - diabolical phenomena - the 'visions, hallucinations, fantasies, revelations, illusory sensations' associated with zazen practice in Zen, which can delude the mystic, and distract her or him from higher Nibbāna realizations (E1 151-152). Indeed, not only can the mystic become stuck at various levels of spiritual experience, she or he can also be overcome and overwhelmed by unconscious contents and energies:

It sometimes happens that the ego is destroyed, that regression in the service of transcendence aborts and degenerates into regression pure and simple. The possibility of such regression is the supreme risk of the Way, and the primary reason for the many resemblances between psychosis and mysticism. Both the psychotic and the mystic have been cast upon the sea of the prepersonal unconscious. The difference is that the mystic's ego is seaworthy, whereas the psychotic's is not. Accordingly, whereas the psychotic capsizes and loses touch with reality, the mystic is

25 Teresa, Interior Castle, pp. 52, 56. Francisco de Osuna devotes a long chapter to this topic of spiritual purgation: 'Remember, brother, in abandoning the world and conquering vice you give the devil more reason to be enraged, and he will feel particular hatred and rancor against you. If it seems he has retreated, beware, for he is busy rearming and mustering stronger forces. ... He will deploy the bad angels he is to burn with in the fire readied for them, and they will shoot you with the wrath, anger, spiritual tribulation, and loathing the evil imaginings and thoughts cause in your soul, and he will fight you unceasingly in a battle that is increasingly vicious the closer it comes.' Third Spiritual Alphabet, p. 183.

${ }^{26}$ Buddhaghosa, Visuddhimagga (Path of Purification), 4th ed. Bhikkhu Nanamoli (trans.) (Kandy, Sri Lanka: Buddhist Publication Society, 2012), pp. 661-665, on the Access to Insight: Readings in Theravāda Buddhism website (2007), available at <http:// www.accesstoinsight.org/lib/authors/nanamoli/PathofPurification2011.pdf $>$ [accessed 3 February 2014]. 
able to survive the voyage to the other side of the sea, finding thereby safe

Ground from which integration can be achieved. (E2 201)

These dramatic and powerful experiences can be quite positive spiritually, if they can be drawn upon to support an ever-deepening self-opening and positive reintegration of the self with spiritual Reality. Ideally, if the mystic can navigate the hazards of this immersion in her personal and pre-personal unconscious, and open to the divine Source, she finds herself transformed and infused by it. The mystic becomes 'progressively more discerning and composed' - 'more lucid and steady' - as she or he personally appropriates the energies and insights of the Dynamic Ground (E2 167). For Teresa, mystical union ultimately involves relatively stable and continuous awareness of divine union that precludes the trance conditions and violent altered transports of the preceding contemplative experiences.

Although Teresa uses some monistic imagery to depict the unitive state - two candle flames united as one, rain that falls into a spring or river, and light that forms in a room from two different windows - she tends also to contextualize the experience theistically. The person participates in divine love and knowledge in union with God, continuously feeling 'within herself this Divine companionship' '[T]he soul remains all the time in that centre with its God. ${ }^{27}$ Buddhaghosa describes perfection more apophatically within his Buddhist interpretive framework, as cessation or unbinding of desire, and insight into the true nature of things. Washburn in his transpersonal perspective speaks of 'regression in the service of transcendence' that is evidenced in traditions crossculturally and cross-religiously, as the mystic finds herself transformed, regenerated, and reconstituted by the spiritual content and energies underlying the realm of the personal unconscious. He postulates an ongoing self-opening to and influence by Spirit: 'It is the process by which all remaining egoic resistances to the power of the Ground are purged and the psyche as a whole is transformed into an unobstructed vehicle of spirit. It is the process of agonizing yet ecstatic opening that renders the egoic sphere completely receptive to spiritual life.' (E2 209)

At the core of the person is what Washburn calls the 'Dynamic Ground' - the activator and enhancer of psychic processes - that within which a newborn is immersed and absorbed in what classical psychoanalysis refers to as original embedment, primary narcissism,

27 Teresa, Interior Castle, pp. 210, 211, 214. 
or oceanic feeling (E2 121, 48). For the infant, this is a self-contained, blissfully contented and fulfilled condition of egoless absorption in our creative Source, which includes not only psychic energy and instinct, but also potential spiritual meaning and possibility (E2 213). It is out of this divine Source - not some subjective psychic phenomenon - that the individuated person emerges, as the infant, toddler, and child gradually differentiates herself from her primary caregiver and later from others, in developing egoic consciousness. This developmental process of individuation naturally represses the primal connection with the Dynamic Ground, which then finds its expression in the person only as active libido or prana or psychic energy. ${ }^{28}$ Mystical meditative practices such as Recollection and Mindfulness meditation gradually remove the original repression and open the mature individual to the awareness of energy and content of the unconscious and the Dynamic Ground, and to the challenges and struggles of integrating these realities with the conscious ego and the body, and expressing them in her life. Ideally, in opening to her spiritual Source, the mystic finds herself eventually immersed in this primal Spirit - as part of it - and a uniquely individual expression of it, in contemplative Union. ${ }^{29}$

\section{CONCLUDING REFLECTIONS}

The paper has clarified and analyzed some of the dynamics of the Christian meditative prayer of Recollection. This form of contemplative meditation involves methods of concentration and receptivity that:

${ }^{28}$ Michael Washburn, Transpersonal Psychology in Psychoanalytic Perspective (Albany, N.Y.: SUNY Press, 1994), p. 314. In his writings Washburn cites major developmental theorists, such as Jean Piaget, Silvano Arieti, and Eric Erikson.

${ }^{29}$ I explore this kind of dynamic of mystic transformation in comparative study of non-dual and theistic mystical experiences, in my book Theo-Monistic Mysticism: A Hindu-Christian Comparison (London: Macmillan Press; N.Y.: St. Martin's Press, 1994). The book postulates and explores various kinds of mystical experience, illustrating how they might be related and integrated within a narrative of spiritual movement and transformation. In this view, radically apophatic non-dual experiences of oneness or unity, which are characterised as static, passive and amoral, prepare and open the mystic to other kinds of mystical experiences, including theistic types. These non-dual, monistic experiences are connected with 'theo-monistic' realizations - mystical experiences which include dynamic and personal elements that are creative and moral, and to which other kinds of mysticism might also be related. This view of mysticism parallels and supports Washburn's transpersonal account in significant ways, and is illustrated in the book in reference to various Hindu and Christian mystics. 
(i) stop sensory awareness and still the ordinary processes of feeling, imagination, memory, and cognition; (ii) contribute to a person's selfawareness of emotional/intellectual patterns and processes, which can lead to positive therapeutic effects upon certain psychological disorders; (iii) stimulate an altered state union with the object of meditative focus, including an awareness of its essential nature; (iv) bring about the movement to apophatic states or conditions of consciousness purity (Quiet) that are characterized by radical stillness, equanimity, serenity, lucidity, humility, and bliss; (v) further open the person through continued mystical ascesis to the personal and pre-personal unconscious, with the conflicts, struggles, and dynamic mystical experiences associated with the phenomena surfacing from these subterranean realms; (vi) and culminate positively in some cases with the personal integration through and with spiritual realities that are associated with deeper mystical experiences of contemplative union that are tranquil, continuous, and expressed by mystics in their active, social contexts.

The paper highlighted apparent common features and effects of Recollection and Buddhist Mindfulness and Insight meditation within this transformative dynamic, and explored a transpersonal psychological account of the difficulties and dangers that mystics across traditions describe with regard to the purgative dynamics of the transformative movement. These meditative practices tend to destabilize the ego and open the spontaneous imagination to unconscious contents and energies - a heightening of autosymbolic imagery that will occur in dream states of sleep, as well as in meditative repose. A practical question is what is the most effective way to respond to this upsurge of unconscious material, in support of the movement to psychic/spiritual integration?

Presumably, that would depend in large part on the emotional and psychological tendencies and needs of the individual, which she or he would have to discern in dialogue with a therapist or spiritual guide or director. This might involve special attention to certain meditative objects or postures or prayers, or an emphasis on one or another therapeutic practice (e.g. dream analysis, journaling, role-playing, sand play therapy, art therapy, etc.), or perhaps various kinds of religious or other social activities. The goal of the dynamic is to enable the person to embrace and reflect the energies and insights of this higher Source, free from unconscious embedded tendencies, which have been brought to conscious awareness through the meditative practices. I assume that the methods that support the liberation of the mystic from these tendencies 
would be dependent on the specific nature and needs of the individual person.

Washburn speaks of non-egoic creative resources of the psyche that are associated with the Dynamic Ground. He suggests that, in contemplative absorption, the ego eventually is drawn or immersed into the Dynamic Ground, loses itself in it, so to speak, and directly experiences aspects of it. Integration requires that the ego recover itself by adjusting and learning to work in harmony with these creative resources. As 'ego', in its renewal it remains the 'focusing lens of the psyche as whole', even though it has no power over the Dynamic Ground. The integrated ego would then approach the world from the perspective of the Dynamic Ground, not in the sense that it can manipulate or control this Reality - for the Dynamic Ground is the very Source of the ego and is non-egoic in nature - but in that the ego can learn to draw the resources of this Reality into the horizon of its intentions. Washburn writes: 'The autosymbolic process continues to work in a spontaneous way, but the ego learns how to guide its spontaneity.' (E2 237)

In my mind, a significant advantage of Washburn's transpersonal theory is that it is not reductionistic in its supposition of very rich and complex spiritual content and activity for what he calls the Dynamic Ground, which is universal, creative, and contains and exudes both non-personal and personal features. His theory does not belittle or deny the sacred, transcendent character of the divine Source, nor make it subsequent to the human ego. The Dynamic Ground is profoundly mysterious: it is the 'psychic underworld', a 'separate cosmic domain', and the source of 'upwelling' and 'renewing life'. Washburn describes it as 'the fertile-sacred' - 'as the space through which transparent Spirit manifests itself in the soul. As a void that is full rather than empty, the fertile-sacred void is full above all with sacred power. For the ego, the fertile-sacred void is the space through which God breathes the divine pneuma into the soul'. ${ }^{30}$

Washburn's account thus includes key features of ultimate Reality postulated in major world religions that traditionally mystics have claimed to encounter directly through prayer and meditative practices. His theory proposes psychological processes that seem plausible and true to the traditional practices and much of the spiritual-theological

${ }^{30}$ Michael Washburn, Embodied Spirituality in a Sacred World (Albany, N.Y.: SUNY Press, 2003), pp. 57-58. 
theory of the mystical traditions he cites as illustration. I should note also that, although he does not refer to Eastern Christian Orthodox spirituality as far as I can tell, that tradition, given its grounding in mystical experience and its stress on askesis (spiritual exercises) and theosis (deification), certainly also reflects many of the transformative dynamics he emphasizes. ${ }^{31}$

I close briefly by discussing some questions related to the Buddhist/ MBCT parallels - comments that might also apply to contemporary Centering Prayer and Christian Meditation, given their significant correspondences with Recollection. I am wondering to what degree Washburn's transpersonal theory might reflect the clinical experiences of MBCT therapists or might come to inform the practice? Do all MBCT clients find themselves eventually confronted by contents and energies of the pre-personal and collective unconscious? I have heard informally one brief account from a MBCT therapist who seemed to suggest this to be the case, but I was not at the time able to follow up for further details. On the other hand, a transpersonal therapist once suggested to me that intention is normally very significant in determining the extent and depth that a person might open both to the personal and prepersonal unconscious. Perhaps there are attitudes or other therapeutic methods that clients might bring to MBCT, by which they are able to resist such radical or extensive de-repression. Also, perhaps there are significant factors beyond contemplative meditation that contribute to the repression or de-repression of unconscious materials. From my own experience, I suspect that people normally go through periods where they are much more open to unconscious upsurges, depending on their life-circumstances, events, and environment, even while maintaining a regular meditative practice.

Moreover, presumably a person might go through periods of very intense psychological upheaval and times of relative stability, rather than a continuous regression, once the opening to unconscious energies and meaning has begun. And, perhaps for many people the regression is simply quite gradual and relatively slow, allowing sufficient time

31 See, for example, Kyriacos C. Markides, 'Eastern Orthodox Mysticism And Transpersonal Theory', The Journal of Transpersonal Psychology, vol. 40/2 (2008), 178198. This paper is perhaps a little overly general and under-critical in approach, and does not explore a great deal of specific transpersonal theory. But it is quite interesting and I think illustrates nicely important features of Eastern Orthodox spirituality that reflect key dynamics of Washburn's transpersonal theory. 
for processing and integration. On these accounts, only in rare cases are people apparently opened to unconscious material that leads to radically debilitating psychoses. But this might mean that some clients in MBCT (and modern practitioners of Centering Prayer and Christian Meditation) must cease their meditation practice at a certain point in the de-repression of unconscious contents and energies, in order to avoid incapacitating psychic conflict or chaos, analogous to the way in which a Jungian analyst will not allow an analysand to do dream work when she or he feels the analysand's ego is not strong enough to withstand upsurges of unconscious material. It also might suggest that MBCT therapists could perhaps helpfully draw transpersonal perspectives into their framework, in adapting their therapeutic methods to clients who desire a deepening of their spiritual experience beyond the response to mood disorders. This suggestion is not to challenge the goal of MBCT, only to suggest that, for some clients, it might be appropriate to broaden the therapeutic context in spiritual ways.

And, lastly, I note in closing that I think Washburn's transpersonal account also highlights possible benefits and dangers of entheogens the use of psychoactive drugs in religious contexts. At least in theory, in the face of very challenging resistances, entheogens might aid a person in opening to psycho-spiritual contexts beyond those experienced via regular meditative or other religious practices, but they might also have very negative effects in stimulating an opening to unconscious contents that are simply overwhelming and destructive. In light of the difficulties, resistances, and obstacles of contemplative meditation, obviously great care and wisdom need to be taken in the inclusion of such chemical substances in religious and mystical practices. ${ }^{32} 33$

${ }^{32}$ For good contemporary discussions of entheogens, see, for example, William A. Richards, 'Here and Now: Discovering the Sacred with Entheogens', Zygon, vol 49, no. 3 (September 2014), 652-665; Huston Smith, Cleansing the Doors of Perception: The Religious Significance of Entheogenic Plants and Chemicals (New York: Jeremy P. Tarcher/ Putnam, 2000); and G. William Barnard, 'The Potential Relevance of Entheogens', Zygon, vol. 49, no 3 (September 2014), 666-684.

${ }^{33}$ This paper was presented at the Philosophy of Religion and Mysticism Conference, Institute of Philosophy, Russian Academy of Sciences, Moscow, Russia, May 22-24, 2014, hosted by Alexey Gaginskiy, Kirill Karpov, and Vladimir Shokhin. I express my gratitude to them and to other participants at the conference, and especially to Michael Rota, the John Templeton Foundation, and the University of St. Thomas, for the invitation and generous support of this event. I am grateful also to Jaegil Lee and Glenn McCullough, for their helpful responses and suggestions to an earlier draft of this paper. 